\title{
Kebijakan Fiskal dan Pertumbuhan Ekonomi Daerah: Bukti Data Panel di Indonesia
}

\author{
Khairul Amri \\ Universitas Islam Negeri Ar-raniry \\ Jl. Syeikh Abdul Rauf, Darussalam, Banda Aceh
}

email : khairul.amri@ar-raniry.ac.id

\begin{abstract}
This study aims to analyze the effect of fiscal policy on regional economic growth in Indonesia. The fiscal policy consists of local government revenue pertains to local taxes and tax revenue-sharing, and local government expenditure includes grant \& social spendings, goods \& services, as well as capital spendings. Using panel data of 28 provinces during the period 2005-2015, then the data were analyzed using the econometric means of the panel regression fixed-effect approach. The study found that on the revenue side, local taxes have a positive effect, and vice versa, the tax revenue-sharing has a negative effect on economic growth. On the expenditure side, the grants \& social spending, and the goods \& services expenditure have a positive and significant effect, and vice versa capital spending has no effect on economic growth.
\end{abstract}

Keywords: Revenues, Expenditure, Panel

\begin{abstract}
Abstrak,
Penelitian ini bertujuan untuk menganalisis pengaruh kebijakan fiskal terhadap pertumbuhan ekonomi regional di Indonesia. Kebijakan fiskal yang dimaksudkan dilihat dari penerimaan pemerintah daerah terdiri dari pajak daerah dan bagi hasil pajak, dan pengeluaran pemerintah daerah meliputi belanja hibah dan bantuan sosial, belanja barang dan jasa dan belanja modal. Menggunakan data panel dari 28 provinsi selama periode 2005-2015, data dianalisis dengan menggunakan peralatan ekonometrika regresi panel pendekatan fixed-effect. Penelitian ini menemukan bahwa di sisi penerimaan, pajak daerah berpengaruh positif, dan sebaliknya, bagi hasil pajak berpengaruh negatif terhadap pertumbuhan ekonomi. Di sisi pengeluaran, belanja hibah \& sosial, dan belanja barang \& jasa berpengaruh positif dan signifikan, dan sebaliknya belanja modal tidak berpengaruh pada pertumbuhan ekonomi.
\end{abstract}

Kata Kunci: Penerimaan, Belanja, Panel

\section{PENDAHULUAN}

Efektivitas kebijakan fiskal dalam meningkatkan pertumbuhan ekonomi telah lama menjadi diskusi akademik dikalangan pengambil kebijakan ekonomi, terutama sejak krisis ekonomi melanda Negara-negara Asia seperti Indonesia, Korea, Thailand, dan Filipina, berlanjutnya resesi di Jepang, dan melemahnya 


\section{Kebijakan Fiskal dan Pertumbuhan Ekonomi Daerah: Bukti Data Panel di Indonesia}

Khairul Amri

perekonomian Amerika Serikat. Dalam kondisi krisis tersebut, peran sektor swasta dalam menggerakkan perekonomian mengalami penurunan yang sangat signifikan. Sehingga pemerintah memiliki peran dominan dalam menyelamatkan perekonomian yang salah satunya melalui stimulus fiskal. Peran kebijakan tersebut telah terbukti mampu mendukung pemulihan ekonomi. Namun, efektifitas stimulus fiskal sebagai subsitusi investasi swasta tetap dipertanyakan (Abimanyu, 2003).

Kebijakan fiskal terdiri atas dua instrumen utama, (1) kebijakan pajak dan (2) pengeluaran pemerintah (Mankiw, 2003). Variabel instrumen kebijakan fiskal dapat berbentuk pajak, transfer pemerintah, subsidi, dan pengeluaran pemerintah (Maipita et al., 2010). Adanya keterkaitan antara kebijakan fiskal dengan pertumbuhan ekonomi dijelaskan dengan berbagai teori. Teori Keynes mengemukakan bahwa pengeluaran pemerintah dapat memberikan dampak positif bagi peningkatan output dalam perekonomian sehingga pertumbuhan ekonomi meningkat. Sedangkan pemungutan pajak oleh pemerintah dapat berdampak negatif. Hal ini berarti bahwa kebijakan fiskal dapat memberikan pengaruh positif atau negatif bagi perekonomian, tergantung pada instrumen yang digunakan. Teori pertumbuhan endogen juga mendukung pandangan bahwa kebijakan fiskal dapat mempengaruhi pertumbuhan ekonomi melalui beberapa jalur, beberapa di antaranya bisa berpengaruh positif, sementara yang lain dapat berpengaruh negatif terhadap pertumbuhan ekonomi (Eros, 2010).

Kebijakan fiskal pemerintah daerah pada dasarnya juga menggunakan dua instrumen utama yakni pemungutan pajak guna mendanai anggaran daerah dan pengeluaran pemerintah yang dialokasikan dalam bentuk berbagai komponen pengeluaran. Kebijakan fiskal pemerintah daerah di Indonesia tercermin dari struktur APBD daerah yang bersangkutan. Secara umum struktur APBD terdiri dari Pendapatan Daerah, Belanja Daerah dan Pembiayaan Daerah. Pendapatan Daerah terdiri dari Pendapatan Asli Daerah (PAD), Dana Perimbangan dan Lainlain Pendapatan yang sah. Sedangkan Belanja terdiri dari Belanja Langsung dan Belanja Tidak Langsung. Terakhir, Pembiayaan Daerah terdiri dari Penerimaan Pembiayaan dan Pengeluaran Pembiayaan.

Selama periode tahun 2010-2015 pertumbuhan ekonomi antar daerah di Indonesia relatif beragam. Di satu sisi ada daerah dengan tingkat pertumbuhan di atas rata-rata nasional, dan di sisi lain terdapat daerah dengan tingkat 
pertumbuhan ekonomi di bawah rata-rata nasional. Hal ini dapat dilihat dari pertumbuhan pendapatan per kapita ril tanpa migas masing-masing provinsi. Gambar 1 memperlihatkan rata-rata pertumbuhan PDRB tanpa migas perkapita 28 provinsi di Indonesia selama periode tahun 2010-2015.

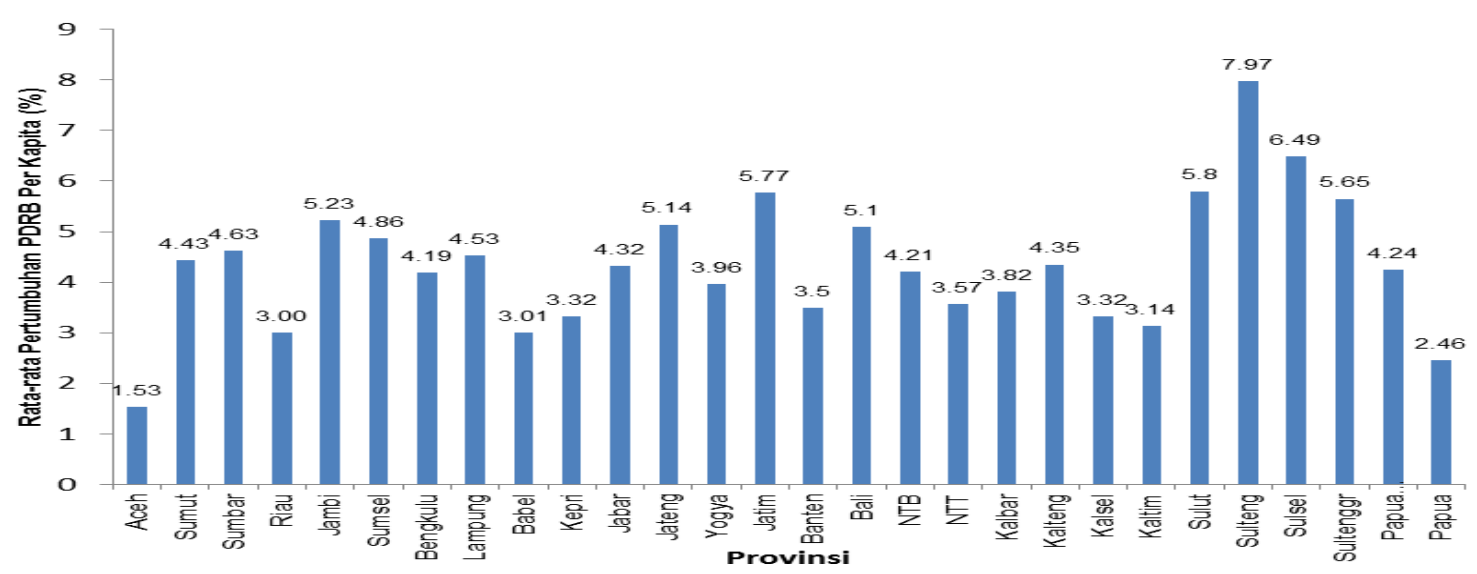

Gambar 1

Rata-rata Pertumbuhan PDRB Per Kapita Tanpa Migas 28 Provinsi Indonesia Berdasarkan Harga Konstan Tahun 2000 Selama Periode Tahun 2010-2015

Pertumbuhan ekonomi suatu daerah tentunya terkait dengan kebijakan fiskal pemerintah daerah yang bersangkutan. Kebijakan fiskal dimaksud baik pada sisi penerimaan maupun sisi pengeluaran daerah. Kebijakan dari sisi penerimaan daerah misalnya yang dalam hal ini dibatasi pada penerimaan pajak daerah, dan bagi hasil pajak antara pusat dan daerah. Penerimaan pajak daerah di Indonesia relatif berbeda antara satu daerah dengan daerah lainnya. Bahkan penerimaan pajak tersebut dalam daerah yang sama cenderung mengalami peningkatan dari tahun ke tahun. Pada tahun 2010, daerah dengan penerimaan pajak daerah relatif kecil adalah Nusatenggara Timur sebesar Rp41.436 per kapita. Angka ini meningkat menjadi sebesar Rp129.425 pada tahun 2015. Di lain pihak, pada tahun 2010 daerah dengan penerimaan pajak daerah paling besar adalah Kalimantan Timur sebesar Rp565.961 per kapita, meningkat menjadi sebesar Rp922.607 pada tahun 2015. Penerimaan pajak per kapita untuk daerah lainnya di Indonesia juga mengalami peningkatan yang sangat signifikan.

Dalam periode yang sama, penerimaan daerah yang bersumber dari bagi hasil pajak justru mengalami penurunan untuk semua provinsi, kecuali Riau, Jambi, Sumsel, dan Nusatenggara Barat. Pada tahun 2010 daerah dengan 


\section{Kebijakan Fiskal dan Pertumbuhan Ekonomi Daerah: Bukti Data Panel di Indonesia}

Khairul Amri

penerimaan bagi hasil pajak paling besar adalah Papua Barat sebesar Rp241.534 per kapita. Pada tahun 2015 angka tersebut menurun menjadi sebesar Rp219.804 per kapita. Sebaliknya daerah dengan penerimaan bagi hasil pajak paling rendah adalah Nusatenggara Timur sebesar Rp14.586 per kapita, turun menjadi sebesar Rp10.995 per kapita pada tahun 2015.

Selanjutnya kebijakan fiskal daerah dari sisi pengeluaran pemerintah daerah dibatasi pada belanja hibah dan bantuan sosial, belanja barang dan jasa dan belanja modal. Pengeluaran pemerintah daerah dalam bentuk hibah dan bantuan sosial juga mengalami peningkatan. Pada tahun 2010 daerah dengan belanja hibah dan bantuan sosial per kapita paling besar adalah Papua Barat sebesar Rp398.885. Kemudian menyusul Aceh di urutan kedua dengan belanja hibah dan bantuan sosial per kapita sebesar Rp287.678. Sebaliknya daerah dengan belanja hibah dan bantuan sosial per kapita paling rendah adalah Jawa Barat sebesar Rp8.072. Hingga tahun 2015, daerah dengan belanja hibah dan bantuan sosial paling besar masih Papua Barat sebesar Rp641.130 per kapita. Kemudian menyusul Papua di urutan kedua sebesar Rp295.186 per kapita.

Pengeluaran pemerintah daerah dalam bentuk belanja barang dan jasa juga mengalami peningkatan yang sangat signifikan. Pada tahun 2010 daerah dengan belanja barang dan jasa per kapita paling besar adalah Papua Barat, kemudian menyusul Papua dan Aceh di urutan kedua dan ketiga. Sebaliknya daerah dengan belanja barang dan jasa per kapita paling rendah adalah Jawa Barat dan Jawa Tengah. Hingga tahun 2015 daerah dengan belanja barang dan jasa paling besar tetap Papua, Papua Barat dan Aceh. Pada tahun yang sama, Jawa Barat dan Jawa Tengah tetap berada di urutan paling bawah bila dibandingkan dengan provinsi lainnya di Indonesia.

Alokasi anggaran daerah dalam bentuk belanja modal juga mengalami peningkatan di setiap daerah, kecuali Aceh, Bangka Belitung dan Kepulauan Riau. Belanja modal per kapita pada tahun 2015 di tiga provinsi tersebut lebih kecil bila dibandingkan dengan belanja yang sama pada tahun 2010. Hal ini mengindikasikan persentase alokasi belanja modal dalam struktur belanja pemerintah daerah Aceh, Bangka Belitung dan Kepulauan Riau semakin kecil seiring dengan meningkatnya belanja pemerintah daerah. Peningkatan belanja modal diharapkan mampu mendorong kegiatan ekonomi masyarakat di daerah yang pada akhirnya berdampak baik bagi pertumbuhan ekonomi dan 
kesejahteraan masyarakat. Apalagi belanja modal merupakan bagian dari belanja pembangunan yang dialokasikan untuk pembangunan infrastruktur publik guna meningkatkan aktivitas ekonomi masyarakat.

Seperti dijelaskan sebelumnya, penerimaan pemerintah daerah di Indonesia mengalami yang bersumber dari pajak daerah mengalami peningkatan dari tahun ke tahun. Demikian pula halnya dengan belanja pemerintah yang dalam hal ini dilihat dari belanja hibah dan bantuan sosial, belanja barang dan jasa serta belanja modal juga mengalami peningkatan yang sangat signifikan. Peningkatan penerimaan dan belanja pemerintah diharapkan dapat meningkatkan pertumbuhan ekonomi di daerah. Namun kenyataannya, pertumbuhan ekonomi sebagian daerah di Indonesia masih relatif rendah. Selama periode tahun 2010-2015, rata-rata pertumbuhan ekonomi di 28 provinsi di Indonesia hanya 4,34 persen per tahun. Hanya Sulawesi Tengah dengan tingkat pertumbuhan relatif tinggi dengan rata-rata sebesar 7,79 persen per tahun. Capaian pertumbuhan ekonomi tersebut kiranya relatif rendah bila dibandingkan dengan peningkatan belanja pemerintah daerah.

Penelitian mengenai keterkaitan antara kebijakan fiskal dan pertumbuhan ekonomi sudah banyak dilakukan oleh peneliti-peneliti sebelumnya. Baik dengan mengambil objek kajian di negara maju, berkembang maupun negara miskin. Namun temuan penelitian yang sudah ada masih memberikan kesimpulan beragam. Kebijakan fiskal dari sisi penerimaan daerah misalnya, penelitian yang dilakukan oleh Mark et al. (2000) dan Holcombe \& Lacombe (2004) menemukan bahwa pajak memiliki dampak negatif terhadap pertumbuhan. Sebaliknya, penelitian Caballero \& López (2012) justru mengungkapkan bahwa pajak berpengaruh positif terhadap pertumbuhan ekonomi. Selanjutnya kajian mengenai keterkaitan antara kebijakan fiskal dari sisi belanja pemerintah dengan pertumbuhan ekonomi juga masih membingungkan. Belanja pemerintah dalam bentuk investasi berdampak positif pertumbuhan ekonomi dalam jangka panjang, namun dalam jangka pendek berpengaruh negatif Matthew \& Udom, 2015). Sebelumnya, hasil kajian Modebe et al. (2012) menemukan bahwa belanja lancar (current expenditure) berdampak positif terhadap pertumbuhan ekonomi. Sedangkan belanja modal berpengaruh negatif tetapi tidak signifikan terhadap pertumbuhan ekonomi. 


\section{Kebijakan Fiskal dan Pertumbuhan Ekonomi Daerah: Bukti Data Panel di Indonesia}

Khairul Amri

Temuan sejumlah peneliti di atas mengisyaratkan bahwa arah pengaruh instrumen kebijakan fiskal (baik sisi penerimaan maupun belanja pemerintah) terhadap pertumbuhan ekonomi masih menjadi pertanyaan terbuka, sehingga menjadi "empirical gap" bagi penelitian lebih lanjut. Karena itu, penelitian ini menguji kembali hubungan fungsional antara pertumbuhan ekonomi dalam kontek perekonomian daerah di Indonesia. Hal ini sangat relevan mengingat pertumbuhan ekonomi daerah relatif berbeda antara daerah yang satu dan daerah yang lain, dan dalam periode waktu yang sama realisasi penerimaan dan belanja pemerintah daerah juga berbeda.

\section{TINJAUAN TEORITIK}

\section{Pertumbuhan Ekonomi Daerah}

Pertumbuhan ekonomi secara sederhana dapat diartikan sebagai kenaikan output total dalam jangka panjang tanpa memandang apakah kenaikan tersebut diikuti oleh pertumbuhan struktur perekonomian atau tidak (Sukirno, 2004:14). Dalam kontek negara, pertumbuhan ekonomi merefleksikan kemampuan atau kapasitas suatu negara untuk menyediakan barang dan jasa bagi penduduknya dalam jangka panjang (Todaro, 2006:99). Kenaikan kapasitas dimaksud ditentukan oleh kemajuan teknologi, institusional, dan ideologis terhadap tuntutan keadaan yang ada. Dalam kontek daerah, pertumbuhan ekonomi pada dasarnya berkaitan dengan efek perpaduan antara produktivitas kerja dan penduduk di daerah tersebut (Pressman, 2000:77).

Perekonomian suatu daerah dapat dikatakan tumbuh apabila nilai barang dan jasa yang dihasilkan oleh penduduk di daerah tersebut mengalami kenaikan dari waktu ke waktu (Hasyim et al., 2019). Sebaliknya, ketika nilai total barang dan jasa yang dihasilkan menurun, maka kondisi tersebut dapat diartikan bahwa daerah yang bersangkutan mengalami penurunan pertumbuhan ekonomi. Pengukuran pertumbuhan ekonomi di suatu daerah dapat didasarkan pada PDRB per kapita (berdasarkan harga konstan periode tahun tertentu) daerah tersebut dalam periode tahun berjalan dan kemudian membandingkannya dengan periode tahun sebelumnya. Ketika pendapatan per kapita meningkat dapat diartikan bahwa pertumbuhan ekonomi meningkat. Sebaliknya, penurunan pendapatan per kapita mengindikasikan adanya penurunan pertumbuhan ekonomi (Amri, 2018). 


\section{Kebijakan Fiskal dan Keterkaitannya dengan Pertumbuhan Ekonomi}

Kebijakan fiskal adalah kebijakan ekonomi yang digunakan pemerintah untuk mengelola/mengarahkan perekonomian ke kondisi yang lebih baik atau diinginkan dengan cara mengubah penerimaan dan pengeluaran pemerintah. Kebijakan fiskal daerah merupakan salah satu kebijakan dalam perekonomian yang dilakukan oleh pemerintah daerah melalui instrumen Anggaran Pendapatan dan Belanja Daerah (APBD). APBD merupakan instrumen untuk mengatur pengeluaran dan pendapatan daerah dalam rangka membiayai pelaksanaan kegiatan pemerintahan dan pembangunan, mencapai pertumbuhan ekonomi, meningkatkan pendapatan masyarakat, mencapai stabilitas perekonomian, dan menentukan arah serta prioritas pembangunan di daerah secara umum. Sebagaimana kebijakan fiskal negara secara umum, kebijakan fiskal di tataran daerah juga mengoperasionalkan dua instrumen utama yakni kebijakan pajak dan pengeluaran pemerintah (Mankiw, 2003). Namun, kebijakan apapun yang secara langsung dapat mempengaruhi perekonomian dari sisi permintaan dapat dikatagorikan sebagai kebijakan fiskal.

Peran kebijakan fiskal dalam proses pertumbuhan ekonomi jangka panjang menjadi krusial dalam ekonomi makro sejak munculnya model pertumbuhan endogen (Paparas, 2015). Hubungan antara kebijakan fiskal pemerintah daerah dengan pertumbuhan ekonomi sudah lama menjadi kajian peneliti ekonomi, namun masih memberikan kesimpulan yang beragam (Peltzman, 2016). Peran kebijakan fiskal terhadap pertumbuhan ekonomi telah mendorong beberapa studi pada tataran teoritis dan empiris (Afonso \& Alegre, 2007). Pemerintah membutuhkan pengetahuan apakah aktivitas publik yang mereka jalankan berfungsi sebagai insentif bagi pertumbuhan atau menimbulkan hambatan, karena pengembangan kebijakan fiskal yang tepat dapat mendorong pertumbuhan ekonomi terus menerus.

Hasil kajian terdahulu berkaitan dengan pengaruh kebijakan fiskal terhadap pertumbuhan ekonomi masih menyajikan hasil yang kontroversial. Kebijakan terkait dengan sisi penerimaan pemerintah misalnya, sejumlah penelitian menemukan bahwa pajak memiliki dampak negatif terhadap pertumbuhan (Holcombe \& Lacombe, 2004; Reed, 2008). Dampak negatif pajak mungkin disebabkan dampak pajak secara langsung menurunkan pendapatan masyarakat. Agak berbeda dengan temuan tersebut, penelitian Samaniego (2014) 


\section{Kebijakan Fiskal dan Pertumbuhan Ekonomi Daerah: Bukti Data Panel di Indonesia}

Khairul Amri

menggunakan data panel di Meksiko mengungkapkan bahwa pajak berdampak negatif terhadap pertumbuhan ekonomi dengan menggunakan model OLS panel data, dan berpengaruh positif dengan model fixed dan random effects. Sebaliknya, bertolak belakang dengan Reed dan Samaniego, hasil penelitian Puonti (2016) menemukan bahwa peningkatan pajak untuk membiayai pengeluaran pemerintah memiliki dampak positif terhadap pertumbuhan. Sama halnya dengan temuan Puounti, penelitian yang dilakukan oleh Ofoegbu et al. (2016) juga memberikan bukti empiris bahwa terdapat hubungan positif dan signifikan antara penerimaan pajak dengan pertumbuhan ekonomi.

Pengaruh instrumen kebijakan fiskal dari sisi pengeluaran terhadap pertumbuhan ekonomi juga belum memberikan kesimpulan yang sama. Belanja publik memiliki pengaruh campuran (mixed effect) terhadap pertumbuhan ekonomi. Beberapa komponen memiliki pengaruh negatif, sementara komponen lain memiliki dampak positif terhadap pertumbuhan ekonomi (Abubakar, 2016). Sebelumnya, Nurudeen \& Usman (2010) menemukan bahwa tidak semua belanja pemerintah dapat memiliki dampak positif terhadap pertumbuhan ekonomi. Belanja modal dan belanja lancar (current expenditure) serta belanja pendidikan memiliki pengaruh negatif terhadap pertumbuhan ekonomi. Sebaliknya peningkatan belanja pemerintah dalam bidang transportasi, komunikasi dan kesehatan dapat meningkatkan pertumbuhan ekonomi.

Adanya arah pengaruh yang berbeda dari instrumen kebijakan fiskal sisi pengeluaran terhadap pertumbuhan ekonomi juga ditemukan oleh Matthew \& Udom (2015) bahwa belanja lancar dalam jangka panjang berpengaruh positif, sedangkan belanja modal dalam jangka pendek justru berpengaruh negatif terhadap pertumbuhan ekonomi. Modebe et al. (2012) juga membuktikan bahwa belanja lancar berdampak positif dan signifikan terhadap pertumbuhan ekonomi. Sedangkan belanja modal berpengaruh negatif tetapi tidak signifikan terhadap pertumbuhan ekonomi. Agak berbeda dengan temuan tersebut, penelitian Akhmad et al. (2013) justru membuktikan bahwa realokasi kebijakan anggaran dengan pengalihan pengeluaran untuk barang dan jasa dan pengeluaran lainnya ke dalam bentuk belanja modal memberikan dampak yang lebih baik terhadap perekonomian regional. Hampir sama dengan temuan Akhmad et al., hasil penelitian Amri \& Aimon (2017) menyimpulkan bahwa alokasi anggaran belanja pemerintah dalam bentuk belanja modal merupakan syarat penting 
pertumbuhan ekonomi. Terutama jika belanja modal tersebut diperuntukan bagi pembangunan infrastruktur publik seperti jalan dan irigasi misalnya, secara langsung dapat berdampak pada perluasan kesempatan kerja dan perkembangan di sektor lainnya termasuk ekspor (Amri \& Nazammudin, 2018) serta peningkatan produktivitas usaha masyarakat yang pada gilirannya mendorong pertumbuhan ekonomi daerah (Amri, 2020).

\section{METODE PENELITIAN}

Dalam penelitian ini, kebijakan fiskal dari dilihat dari sisi penerimaan dan pengeluaran pemerintah daerah yang tercermin dari realisasi penerimaan dan belanja pemerintah. Instrumen kebijakan fiskal dari sisi penerimaan dibatasi pada pajak daerah dan bagi hasil pajak daerah. Selanjutnya dari sisi pengeluaran dibatasi pada belanja hibah dan bantuan sosial, belanja barang dan jasa, dan belanja modal. Data yang digunakan adalah data sekunder. Data tersebut berbentuk panel data terdiri dari data time series (runut waktu) selama periode tahun 2010-2015 $(\mathrm{n}=6)$ dan data silang (cross-section data) 28 provinsi di Indonesia. Variabel yang dioperasionalkan terdiri dari pertumbuhan ekonomi, penerimaan pajak, bagi hasil pajak, belanja hibah dan bantuan sosial, belanja barang dan jasa dan belanja modal. Pertumbuhan ekonomi diproxi dari PDRB per kapita berdasarkan harga konstan tahun 2010 dinyatakan dalam satuan ribu rupiah per kapita. Selanjutnya penerimaan pajak dan bagi hasil pajak adalah realisasi penerimaan pajak daerah dan bagi hasil pajak daerah yang dihitung dengan satuan rupiah per kapita. Demikian pula halnya dengan belanja hibah dan bantuan sosial, belanja barang dan jasa, dan belanja modal yakni realisasi ketiga jenis belanja tersebut yang juga dihitung dengan satuan rupiah per kapita.

Model analisis data yang digunakan untuk mengestimasi pengaruh kelima instrumen kebijakan fiskal tersebut terhadap pertumbuhan ekonomi daerah adalah regresi panel. Penggunaan model ekonometrika tersebut didasarkan pada alasan bahwa data yang digunakan dalam kajian ini adalah data panel yakni gabungan antara time series data (2010-2015) dan cross-section data (28 provinsi di Indonesia). Agar koefisien estimasi yang diperoleh melalui regresi panel dapat diinterpretasikan sebagai elastisitas predictor variable terhadap pertumbuhan ekonomi, maka seluruh variabel ditransformasikan dalam bentuk 


\section{Kebijakan Fiskal dan Pertumbuhan Ekonomi Daerah: \\ Bukti Data Panel di Indonesia}

Khairul Amri

logaritma. Sehingga model regresi panel yang merepresentasikan hubungan fungsional antar variabel seperti ditunjukkan dalam persamaan 1.

$\mathrm{LPDRB}_{\text {it }}=\beta_{\mathrm{o}}+\beta_{1} \mathrm{LPD}_{\mathrm{it}}+\beta_{2} \mathrm{LBHP}_{\mathrm{it}}+\beta_{4} \mathrm{LBHS}_{\mathrm{it}}+\mathrm{LBBJ}_{\mathrm{it}}+\beta_{6} \mathrm{LBM}_{\mathrm{it}}+e_{\mathrm{it}}(1)$

Dimana

$\beta_{0} \quad$ : Konstanta

LPDRB $_{\text {it }}$ : Logaritma PDRB per kapita di provinsi i pada periode $t$ (sebagai proxy pertumbuhan ekonomi)

$\mathrm{LPD}_{\text {it }} \quad$ : Logaritma realisasi penerimaan pajak per kapita provinsi i pada periode $t$

$\mathrm{LBHP}_{\text {it }} \quad$ : Logaritma realisasi penerimaan bagi hasil pajak per kapita provinsi i pada periode $t$

LBHS $_{\text {it }}$ : Logaritma realisasi belanja hibah dan bantuan sosial per kapita provinsi i pada periode $t$

LBBJ $_{\text {it }}$ : Logaritma realisasi belanja barang dan jasa per kapita provinsi i pada periode $t$

$\mathrm{LBM}_{\mathrm{it}} \quad$ : Logaritma realisasi belanja modal per kapita provinsi i pada periode $\mathrm{t}$

$\beta_{1}, \beta_{2}, \beta_{3}, \beta_{4}$ dan $\beta_{5}$ : Koefisien estimasi LPD $D_{i t}, L_{B H P} P_{i j}, \beta_{4} L_{B H S} S_{i j}, L_{B B} J_{i t}$, dan $\operatorname{LBM}_{i j}$

$e_{\text {it }} \quad$ : Error term

Regresi panel memiliki tiga pendekatan yaitu common effect model, fixed

effect model dan random effect model (Amri, 2019a). Untuk menentukan mana di antara tiga pendekatan tersebut yang dinilai paling akuratuntuk memprediksi pengaruh kelima instrument kebijakan fiskal terhadap pertumbuhan ekonomi daerah digunakan Chow test dan Hausman test. Chow test digunakan untuk menentukan mana di antara dua metode (common effect model dan fixed effect model) yang dinilai lebih baik. Sedangkan Hausman test digunakan untuk memutuskan apakah model regresi yang digunakan fixed effect atau random effect model (Muliadi \& Amri, 2019).

\section{HASIL DAN PEMBAHASAN}

\section{Hasil Statistik Deskriptif}

Sebagaimana dijelaskan sebelumnya, pertumbuhan ekonomi daerah di Indonesia relatif berbeda satu sama lain. Di satu sisi terdapat daerah dengan pertumbuhan ekonomi relatif lebih tinggi di atas rata-rata nasional, dan sebaliknya sejumlah daerah memiliki pertumbuhan relatif rendah. Penerimaan pemerintah daerah dalam bentuk pajak daerah dan bagi hasil pajak juga relatif berbeda antara daerah yang satu dan daerah yang lain. Demikian pula halnya dengan belanja daerah yang dalam hal ini dibatasi hanya pada belanja hibah dan bantuan sosial, belanja barang dan jasa dan belanja modal, juga terdapat 
perbedaan antar daerah. Menggunakan data 28 provinsi di Indonesia selama periode tahun 2010-2015, hasil statistik deskriptif PDRB per kapita sebagai proxi pertumbuhan ekonomi daerah, dan lima variabel lainnya sebagai instrumen kebijakan fiskal daerah ditunjukkan dalam Tabel 1.

\section{Tabel 1}

Hasil Statistik Deskriptif dan Korelasi Antar Variabel

\begin{tabular}{|c|c|c|c|c|c|c|}
\hline \multicolumn{7}{|c|}{ Statistik Deskriptif } \\
\hline & $\begin{array}{c}\text { PDRB } \\
\text { (Rpooo/ } \\
\text { Kapita }\end{array}$ & $\begin{array}{c}\text { PD } \\
\text { (Rp/Kapita) }\end{array}$ & $\begin{array}{c}\text { BHP } \\
\text { (Rp/Kapita) }\end{array}$ & $\begin{array}{c}\text { BHS } \\
\text { (Rp/Kapita) }\end{array}$ & $\begin{array}{c}\text { BBJ } \\
\text { (Rp/Kapita) }\end{array}$ & $\begin{array}{c}\text { BM } \\
\text { (Rp/Kapita) }\end{array}$ \\
\hline Mean & $8.804,46$ & $283.316,00$ & $55.838,59$ & $146.544,10$ & $244.036,40$ & $215.680,40$ \\
\hline Median & $8.185,36$ & $242.190,70$ & $31.974,78$ & $128.738,60$ & $148.673,70$ & $126.819,30$ \\
\hline Maximum & $27 \cdot 370,29$ & $1.367 .676,00$ & $615.159,00$ & $716.407,90$ & $1.795 .939,00$ & $1.924 .273,00$ \\
\hline Minimum & $2.666,02$ & $41.436,32$ & $10.564,55$ & $8.071,05$ & $333.92,59$ & $12.929,28$ \\
\hline Obs & 168 & 168 & 168 & 168 & 168 & 168 \\
\hline \multicolumn{7}{|c|}{ Korelasi antar variabel } \\
\hline PDRB & 1 & & & & & \\
\hline PD & 0,753 & 1 & & & & \\
\hline BHP & 0,591 & 0,375 & 1 & & & \\
\hline BHS & 0,346 & 0,385 & 0,467 & 1 & & \\
\hline BBJ & 0,402 & 0,314 & 0,631 & 0,668 & 1 & \\
\hline BM & 0,349 & 0,323 & 0,673 & 0,566 & 0,838 & 1 \\
\hline
\end{tabular}

\section{Pemilihan Model Regresi Panel}

Sebagaimana dijelaskan sebelumnya, penggunaan regresi panel untuk mengestimasi hubungan fungsional antar variabel yang datanya berbentuk data panel, menggunakan tiga pendekatan yakni common effect, fixed effect dan random effect. Proses justifikasi ekonometrik guna menentukan mana di antara tiga pendekatan tersebut yang dianggap memberikan hasil estimasi paling tepat, digunakan Chow test dan Hausman test.

Uji Chow test untuk menentukan apakah model yang dipilih common effect atau fixed effect didasarkan pada nilai p-value untuk cross-section $F$ dengan ketentuan jika p-value> 0,05 maka model adalah common effect. Sebaliknya jika $p$-value< 0,05 maka model yang dipilih adalah fixed effect. Hasil uji Chow test ditunjukkan dalam Tabel 2.

Tabel 2

Hasil Chow Test

\begin{tabular}{lllccc}
\hline \multicolumn{1}{c}{ Uji Efek } & & Statistic & df & $p$-value \\
\hline Cross-Section & Fixed & Cross-section F & 272,461 & $(27,135)$ & O,ooo \\
Effects & & Cross-section Chi-square & 674,729 & 27 & 0,ooo \\
& & & & &
\end{tabular}




\section{Kebijakan Fiskal dan Pertumbuhan Ekonomi Daerah: \\ Bukti Data Panel di Indonesia}

Khairul Amri

Berdasarkan Tabel 2 di atas dapat dilihat bahwa nilai $p$-value cross section $\mathrm{F}$ sebesar 0,000 < 0,05. Dengan demikian dapat disimpulkan bahwa berdasarkan uji Chow test, pendekatan yang dipilih adalah fixed effect.

Selanjutnya uji Haussman test digunakan untuk menentukan apakah model yang dipilih fixed effect atau random effect. Pemilihan salah satu di antara kedua pendekatan tersebut didasarkan pada nilai $p$-value cross-section random dengan ketentuan jika nilai $p$-value > 0,05 maka model yang dipilih adalah random effect. Sebaliknya jika nilai $p$-value $<0,05$ maka pendekatan yang dipilih adalah fixed effect. Hasil uji Haussman test seperti ditunjukkan dalam Tabel 3.

Tabel 3

Hasil Haussman Test

\begin{tabular}{cccc}
\hline Uji Efek & $\mathrm{X}^{2}$-Statistic & Chi-Sq. d.f & $p$-value \\
\hline Cross-Section Random Effects & 47,549 & 5 & o,ooo \\
\hline
\end{tabular}

Berdasarkan Tabel 3 dapat dilihat bahwa nilai X²-Statistik sebesar 47,549 dan nilai $p$-value sebesar o,ooo dapat disimpulkan bahwa pendekatan fixed effect lebih baik bila dibandingkan dengan pendekatan random effect. Sebelumnya hasil Chow test juga mengindikasikan bahwa model terbaik juga pendekatan fixed effect.

Justifikasi statistik yang menyimpulkan bahwa pendekatan fixed effect dinilai lebih baik dibandingkan random effect juga dapat didasarkan pada perbandingan grafik residual yang dihasilkan oleh kedua metode tersebut. Untuk lebih jelasnya dapat dilihat Gambar 2 dan gambar 3.

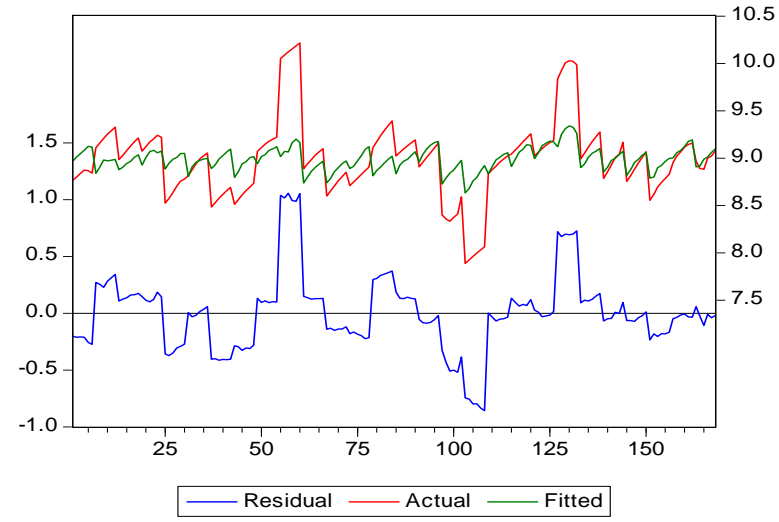

Gambar 2

Residual Metode Random Effect Model

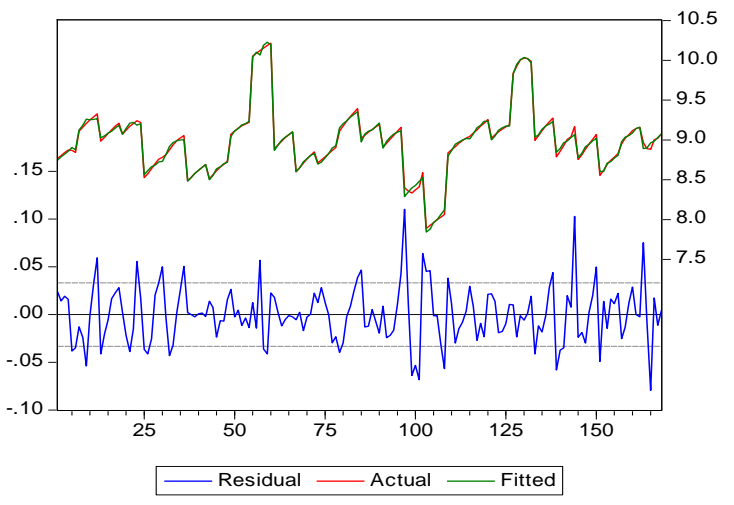

Gambar 3 Residual Metode Fixed Effect Model 
Gambar adalah grafik residual yang dihasilkan dari pendekatan random effect. Pada grafik tersebut terlihat bahwa variasi/fluktuasi garis actual cenderung berbeda dengan fluktuasi garis fitted. Selanjutnya Gambar 3 memperlihatkan residual regresi panel yang dihasilkan oleh pendekatan fixed effect. Pada grafik tersebut terlihat bahwa variasi/fluktuasi garis actual hampir sama dengan fluktuasi garis fitted. Berdasarkan perbandingkan garis actual dan garis fitted pada kedua gambar tersebut juga dapat disimpulkan bahwa pendekatan fixed effect menghasilkan estimasi yang lebih akurat bila dibandingkan dengan random effect. Karena itu, regresi panel yang dipilih dan kemudian digunakan untuk kepentingan analisis dalam penelitian ini adalah regresi panel dengan pendekatan fixed effect.

\section{Hasil Estimasi}

Kebijakan fiskal dari sisi penerimaan memiliki pengaruh berbeda terhadap perekonomian daerah di Indonesia. Pajak daerah berpengaruh positif dan signifikan terhadap pertumbuhan ekonomi, sebaliknya bagi hasil pajak berpengaruh negatif dan signifikan. Pengaruh kebijakan fiskal dari sisi belanja pemerintah juga relatif berbeda. Belanja hibah \& bantuan sosial dan belanja barang \& jasa berpengaruh positif dan signifikan. Sebaliknya belanja modal berpengaruh positif namun tidak signifikan terhadap pertumbuhan ekonomi. Untuk lebih jelasnya dapat dilihat rangkuman hasil regresi panel dengan pendekatan fixed-effect dalam Tabel 4.

Tabel 4

Hasil Regresi Panel Fixed Effect Model

\begin{tabular}{|c|c|c|c|c|}
\hline Variable & $\begin{array}{c}\text { Koefisien } \\
\text { Estimasi } \\
\end{array}$ & Std. Error & t-Statistic & p-value \\
\hline $\mathrm{C}$ & 6,559 & 0,244 & 26,876 & 0,000 \\
\hline LPD & 0,124 & 0,021 & 5,778 & 0,000 \\
\hline LBHP & $-0,044$ & 0,013 & $-3,425$ & 0,001 \\
\hline LBHS & 0,028 & 0,005 & 5,189 & 0,000 \\
\hline LBBJ & 0,075 & 0,015 & 4,923 & 0,000 \\
\hline LBM & 0,012 & 0,009 & 1,278 & 0,203 \\
\hline
\end{tabular}

Berdasarkan Tabel 4 di atas, maka model regresi panel yang menunjukkan hubungan fungsional antara pertumbuhan ekonomi daerah dengan instrumen kebijakan fiskal dapat dinyatakan dalam persamaan 2. 


\section{Kebijakan Fiskal dan Pertumbuhan Ekonomi Daerah: Bukti Data Panel di Indonesia}

Khairul Amri

$$
\begin{aligned}
\mathrm{LPDRB}_{\mathrm{it}}= & 6,559+0,124 \mathrm{LPD}_{\text {it }}-0,044 \mathrm{LBHP}_{\mathrm{it}}+0,028 \mathrm{LBHS}_{\mathrm{it}}+0,075 \mathrm{LBBJ}_{\mathrm{it}} \\
& +0,012 \mathrm{LBM}_{\mathrm{it}}+e_{\mathrm{it}}
\end{aligned}
$$

(2)

Pajak daerah berpengaruh positif terhadap pertumbuhan ekonomi dareah ditunjukkan oleh koefisien estimasi sebesar 0,124 ( $p$-value < 0,05). Temuan ini konsisten dengan hasil kajian Caballero dan López (2012), dan Samaniego (2014) dalam kasus perekonomian Meksiko yang menyajikan bukti empiris bahwa dengan menggunakan regresi panel metode fixed-effect, pajak berpengaruh positif terhadap pertumbuhan ekonomi. Adanya dampak positif pajak daerah terhadap pertumbuhan ekonomi daerah mengindikasikan bahwa pemungutan pajak daerah oleh pemerintah daerah di Indonesia tidak memiliki dampak destruktif terhadap kegiatan ekonomi masyarakat. Ketika pertumbuhan ekonomi meningkat yang diindikasikan oleh peningkatan pendapatan masyarakat, maka kemampuan wajib pajak untuk membayar pajak daerah juga semakin baik. Sehingga kenaikan dalam penerimaan pajak daerah berhubungan searah dengan pertumbuhan ekonomi di daerah. Bahkan hubungan antara pertumbuhan ekonomi dan pajak daerah bersifat dua arah (bidirectional causality), penerimaan pajak mendorong pertumbuhan ekonomi, dan pertumbuhan ekonomi juga dapat mempengaruhi penerimaan pajak (Amri et al., 2019). Hal inilah yang menyebabkan koefisiensi estimasi penerimaan pajak terhadap pertumbuhan ekonomi daerah bertanda positif dan signifikan.

Adanya pengaruh positif dan signifikan pajak daerah terhadap pertumbuhan ekonomi daerah di Indonesia, sejalan dengan hasil penelitian Ofoegbu et al. (2016) yang juga memberikan bukti empiris bahwa terdapat hubungan positif dan signifikan antara penerimaan pajak dengan pertumbuhan ekonomi. Namun, bertolak belakang dengan hasil kajian Mark et al. (2000) dan Reed (2008) yang membuktikan bahwa pajak berpengaruh negatif terhadap pertumbuhan ekonomi. Kedua peneliti tersebut berargumen bahwa dampak negatif pajak terhadap pertumbuhan output disebabkan pajak dapat menurunkan pendapatan masyarakat.

Berbeda dengan pengaruh pajak daerah, bagi hasil pajak justru berpengaruh negatif dan signifikan terhadap pertumbuhan ekonomi daerah di Indonesia, dengan koefisien estimasi sebesar - 0,044 ( $\mathrm{p}$-value < 0,05). Hal ini mengindikasikan bahwa semakin tinggi bagi hasil pajak semakin rendah pertumbuhan ekonomi. Sebaliknya, penurunan bagi hasil pajak berdampak pada 
kenaikan pertumbuhan ekonomi. Temuan ini sangat mengejutkan, mengingat bagi hasil pajak daerah pada dasarnya merupakan penerimaan daerah yang bersumber dari adanya pembagian hasil pemungutan pajak antara pusat dan daerah. Adanya pengaruh negatif dan signifikan variabel tersebut terhadap pertumbuhan ekonomi daerah secara statistik menginformasikan bahwa upaya pemerintah daerah dalam meningkatkan penerimaan daerah yang bersumber dari bagi hasil pajak daerah memiliki dampak destruktif terhadap kegiatan ekonomi masyarakat.

Dari sisi pengeluaran terlihat bahwa belanja pemerintah daerah memiliki pengaruh yang tidak sama terhadap pertumbuhan ekonomi. Belanja hibah \& bantuan sosial dan belanja barang \& jasa berpengaruh positif dan signifikan dengan koefisien estimasi kedua jenis belanja tersebut masing-masing sebesar 0,028 dan 0,075. Semakin besar realisasi belanja hibah dan bantuan sosial semakin tinggi pertumbuhan ekonomi daerah. Sebaliknya, penurunan tersebut berdampak signifikan terhadap penurunan pertumbuhan ekonomi. Demikian pula halnya, kenaikan belanja barang dan jasa berdampak secara nyata terhadap pertumbuhan ekonomi daerah di Indonesia. Temuan ini sejalan hasil penelitian Modebe et al. (2012) menemukan bahwa belanja lancar berdampak positif dan signifikan terhadap pertumbuhan ekonomi. Hasil penelitian ini juga mendukung temuan penelitian Desmon et al. (2012) yang mengungkapkan bahwa belanja barang dan jasa dan belanja sosial berpengaruh positif dan signifikan terhada pertumbuhan ekonomi.

Berbeda dengan belanja hibah \& bantuan sosial dan belanja barang \& jasa, pengaruh belanja modal terhadap pertumbuhan ekonomi daerah di Indonesia, kendatipun positif tetapi tidak signifikan. Hal ini menginformasikan bahwa peningkatan realisasi belanja modal di suatu daerah tidak secara nyata dapat meningkatkan pertumbuhan ekonomi di daerah tersebut. Temuan ini mengkonfirmasi temuan penelitian Modebe et al. (2012) yang membuktikan bahwa belanja modal tidak berpengaruh signifikan terhadap pertumbuhan ekonomi. Tidak signifikannya pengaruh belanja modal terhadap pertumbuhan ekonomi dapat disebabkan oleh dua faktor. Pertama, dampak belanja tersebut terhadap perkembangan ekonomi masyarakat membutuhkan rentang waktu tertentu. Apalagi ketika belanja modal dialokasikan untuk membangun infrastruktur fisik seperti jalan, jembatan, irigasi dan bangunan fisik lainnya yang 


\section{Kebijakan Fiskal dan Pertumbuhan Ekonomi Daerah: Bukti Data Panel di Indonesia}

Khairul Amri

dampak ekonominya merupakan dampak jangka panjang (Amri, 2019b). Bahkan proses pembangunan infrastruktur fisik tersebut dapat menganggu kegiatan ekonomi masyarakat dalam jangka pendek. Apalagi jika proses pembangunan memerlukan waktu lama (proyek multiyears misalnya). Dampak pembangunan infrastruktur fisik bagi perkembangan ekonomi masyarakat hanya terwujud terjadi setelah pembangunan infrastruktur tersebut berakhir. Kedua, pemerintah daerah kurang mampu menentukan program prioritas dalam mengalokasikan belanja modal. Kendatipun pengalokasian belanja tersebut dimaksudkan untuk membangun infrastruktur fisik, namun ketika perencanaan pembangunan dilakukan tanpa memperhitungkan urgensi manfaatnya bagi perkembangan berbagai sektor perekonomian, maka dampak ekonomi pembangunan infrastruktur tersebut dalam mendukung kegiatan ekonomi masyarakat sangat kecil.

\section{KESIMPULAN}

Penelitian ini menemukan bahwa instrumen kebijakan fiskal dari sisi penerimaan memiliki pengaruh berbeda terhadap pertumbuhan ekonomi. Pajak daerah berpengaruh positif dan signifikan, dan sebaliknya bagi hasil pajak daerah berpengaruh negatif dan signifikan terhadap pertumbuhan ekonomi. Selanjutnya kebijakan fiskal dari sisi belanja pemerintah, menunjukkan bahwa belanja hibah dan bantuan sosial, dan belanja barang dan jasa berpengaruh positif dan signifikan terhadap pertumbuhan ekonomi. Sedangkan belanja modal berpengaruh positif tetapi tidak signifikan.

\section{DAFTAR PUSTAKA}

Abimanyu, A., (2005). Fiscal policy and effectiveness of fiscal stimulus in Indonesia Application model of macro-mofi and CGE indorani. Indonesian Economic Journal, 6(1), 1-35.

Abubakar, A. B. (2016). Dynamic effects of fiscal policy on output and unemployment in Nigeria: An econometric investigation, Journal of Applied Statistics, 7(2), 101-122.

Afonso, A., Schuknecht, L., \& Tanzi. (2008). Income distribution determinants and public spending efficiency, Working Paper Series No. 861, European Central Bank.

Akhmad, Achsani, N. A., Tambunan, M., \& Mulyo, S. A. (2013). The Impact of fiscal policy on the regional economy: Evidence from South Sulawesi, Indonesia, Journal of Applied Sciences Research, 9(4), 2463-2474. 
Amri, K. (2017). Indek harga konsumen dan belanja modal terhadap indek perilaku korupsi, SI-MEN (Akuntasi dan Manajemen), 8(1), 49-65.

Amri, K. (2018). The macroeconomic impact of regional minimum wages: A cross-province data evidence from Indonesia, Regional Science Inquiry, 10(3), 163-176.

Amri, K. (2019a). Pengaruh zakat dan kesempatan kerja terhadap tingkat kemiskinan di Aceh, Jurnal Al-Muzara'ah, 7 (2), 55-70.

Amri, K. (2019b). Apakah infrastruktur jalan mempengaruhi ekspor? Pendekatan vector autoregressive, Inovbiz: Jurnal Inovasi Bisnis, 7(2), 166-173.

Amri, K. (2020). Infrastruktur jalan dan kesempatan kerja di Indonesia: Pendekatan vector autoregressive, Jurnal Ilmiah Ekonomi dan Bisnis, 17(1), 85-97.

Amri, K., \& Aimon, H. (2017). pengaruh pembentukan modal dan ekspor terhadap pertumbuhan ekonomi Indonesia, Economac: Jurnal Ilmiah Ilmu Ekonomi 1 (1), 1-16.

Amri, K., \& Nazamuddin. (2018). Is there causality relationship between export and employment: A time series data evidence from Indonesia, International Journal of Academic Research in Economics and Management Science, 7(2), 86-99.

Amri, K., Nazamuddin., Masbar, R., \& Aimon, H. (2019). Is there a causality relationship between local tax revenue and regional economic growth? A panel data evidence from Indonesia, Regional Science Inquiry, 11(1), 73-84.

Caballero, E., \& López J. (2012), Gasto público, impuesto sobre la renta e inversión privada en México. Investigación Económica, 71(280), 55-84.

Desmon, N. I., Titus, O. A., Timothy, O. C., \& Odich, N. L. (2012). Effects of public expenditure on economic growth in Nigeria: a disaggregated time series analysis, International Journal of Management Sciences and Business Research, 1(7), 2-16.

Eros, A. (2010). Long run growth effects of fiscal policy: A case study of Hungary, Club of Economics in Miskolc, 5(1), 11-17.

Hasyim, S., Zulhilmi, M., \& Amri, K. (2019). Is there a causality relationship between law enforcement, crime rates, and economic growth? An empirical evidence from western Indonesia, Regional Science Inquiry, 11 (3), 95-109.

Holcombe, R. G., Lacombe, D. J. (2004), Factors underlying the growth of local government in the 19th Century United States. Public Choice, 120(3-4), 359-377.

Maipita, I., Jantan, M. D., \& Razak, N. A. A. (2010). dampak kebijakan fiskal terhadap kinerja ekonomi dan angka kemiskinan di Indonesia, Buletin Ekonomi Moneter dan Perbankan, 421-456.

Mankiw, N. G. (2003). Macroeconomics. Fifth Edition. Worth Publisher, New York

Mark, S.T., McGuire, T.J., Papke, L.E. (2000), The Influence of taxes on employment and population growth: Evidence from the Washington, D.C. Metropolitan Area. National Tax Journal, 53(1), 105-123. 


\section{Kebijakan Fiskal dan Pertumbuhan Ekonomi Daerah: \\ Bukti Data Panel di Indonesia}

Khairul Amri

Matthew, O., \& Udom, E. (2015). Estimating the impact of the components of public expenditure on economic growth in Nigeria (a bound testing approach), International Journal of Economics, Commerce and Management, 3(3), 1-8.

Modebe, N.J., Okafor, R. G., Onwumere, J. U. J., \& Ibe, I. G. (2012). Impact of recurrent and capital expenditure on Nigeria's economic growth, European Journal of Business and Management, 4(19), 66-74.

Muliadi, M., \& Amri, K. (2019). Penerimaan zakat dan penurunan kemiskinan di Aceh: Peran dana otonomi khusus sebagai pemoderasi, Jurnal Ilmiah Ekonomi Islam, 5(3), 231-242.

Nurudeen, A., \& Usman, A. (2010). Government expenditure and economic growth in Nigeria, 1970-2008: A disaggregated analysis, Business and Economics Journal, 4, 1-11.

Ofoegbu, G. N., Akwu, D. O., \& Oliver, O. (2016). Empirical analysis of effect of tax revenue on economic development of Nigeria, International Journal of Asian Social Science, 6(10): 604-613.

Paparas, D., Richter, C., \& Paparas, A. (2015). Fiscal policy and economic growth, empirical evidence in European union, Turkish Economic Review, 2(4), 239-268.

Peltzman, S. (2016). State and local fiscal policy and growth at the border, Journal of Urban Economics, 95, 1-15.

Pressman, S. (2000). Lima Puluh Pemikir Ekonomi Dunia, Terjemahan Edisi Pertama, Jakarta : PT Raja Grafindo Persada.

Puonti, P. (2016). Fiscal multipliers in a structural VEC model with mixed normal errors, Journal of Macroeconomics 48, 144-154.

Reed, W.R. (2008), The robust relationship between taxes and U.S. state income growth. National Tax Journal, 61(1), 57-80.

Samaniego, M. (2014), Gasto publico productivo y crecimiento económico en México, 1993-2011, in Sánchez, I. L. (Ed.) Reflexiones Sobre Sociedad y Desarrollo en México, 37-76, Ciudad Juárez: Editorial Tiempo Económico \& Lulu.

Sukirno, S, (2004). Makro Ekonomi, Rajawali Press, Jakarta.

Todaro, M. P., \& Smith, S. C. (2006). Economic Development, Eighth Edition, United Kingdom Pearson Education Limited.. 